\title{
HPV status and its genomic integration affect survival of patients with cervical cancer
}

\author{
M. IBRAGIMOVA ${ }^{1,2, *}$, M. TSYGANOV ${ }^{1}$, O. SHPILEVA ${ }^{1}$, O. CHURUKSAEVA ${ }^{1}$, V. BYCHKOV ${ }^{1}$, L. KOLOMIETS ${ }^{1,3}$, N. LITVIAKOV $^{1,2}$ \\ ${ }^{1}$ Tomsk National Research Medical Center of the Russian Academy of Sciences, Tomsk, Russia; ${ }^{2}$ National Research Tomsk State University, \\ Tomsk, Russia; ${ }^{3}$ Siberian State Medical University, Tomsk, Russia \\ *Correspondence: imk1805@yandex.ru
}

Received May 21, 2017 / Accepted July 22, 2017

\begin{abstract}
The aim of this study is the evaluation of relapse-free and overall survival of HPV-positive patients with regard to the physical status of type $16 \mathrm{HPV}$ and of HPV-negative patients with primary cervical cancer. As a main result of the study, the predictive value of the physical status of type $16 \mathrm{HPV}$ was determined for relapse-free and overall survival of patients with cervical cancer. Episomal form of the virus is a favorable predictive factor. Integrated form of the virus is a severely unfavorable predictive factor and survival of such patients is significantly lower than of HPV-patients and patients with mixed form of the virus. The results of the research are data on survival of patients with cervical cancer depending on the physical status of the virus (for HPV+ patients) and of patients with HPV-negative cancer.
\end{abstract}

Key words: HPV, genomic integration, cervical cancer

According to the latest epidemiological data, cervical cancer (CC) is sixth in incidence in Russian women and third in incidence among diseases of female reproductive system after breast cancer and uterine cancer. Morbidity and mortality from this oncopathology in Russia are high - last year showings indicated 6522 and 4248 women, respectively [1]. Besides, the recent years have shown a steady growth in incidence of malignant epithelial cervical tumors connected with human papilloma virus (HPV) of high risk, which is the main causative factor of cervical carcinogenesis [2, 3]. Having entered an organism, HPV infects the basal layer of epithelium in the area of cervix transformation. After penetrating a basal cell of stratified squamous epithelium, the high-risk HPV DNA released from its capsid enters a nucleus, where it is supported as an episome. HPV persistence may be followed by HPV DNA integration into the genome of cells in cervix epithelium, which further leads to genomic instability, disruption of apoptosis, and is a key factor of malignant transformation in cervix epithelium cells [4]. HPV-DNA integration followed by a decrease in E2 virus protein functional activity leads to hyper-expression of E6 and E7 virus proteins [5]. Thus, the virus DNA may exist in an infected cell in various states: episomal form (out of the cell chromosomes), integrated form (integrated into the cell genome), and mixed form (there are free virus DNA and integrated into the host-cell genome DNA) [6].
According to various research, up to $80-90 \%$ of patients diagnosed with CC in Russia are carriers of high-risk HPV [7], so $10-20 \%$ of cervical tumors do not contain the virus. This gives reasons to suggest that a certain number of tumors may occur without this group of viruses (or the virus is eliminated during carcinogenesis), i.e. the tumors are HPV-negative. Some researchers believe that detection of this subtype of CC not associated with the virus is possible only if there are inaccuracies in laboratory research [8]. There is another point of view: HPV-negative tumors do not occur only in HPV-associated CC, but they belong to a more aggressive group, and their carcinogenesis differs significantly from the development mechanisms of HPV-positive tumors [9].

Study of head and neck tumors showed that HPV-negative tumors have higher relapse and mortality rates than HPV+ tumors $[10,11,12]$. Meta-analyses of squamous head and neck tumors showed that HPV-positive patients have higher overall and relapse-free survival $[13,14,15]$. Identical results were obtained from patients with anus tumors. Compared to HPV16-negative patients, the HPV16-positive group of patients showed high rates of 4-year relapse-free survival $(63.1 \%$ to $15.6 \%, \mathrm{p}<0.001)$ and overall survival $(84.6 \%$ to $39.8 \%, \mathrm{p}=0.008$ ) [16]. Study involving 84 patients with CC showed a much lower relapse-free and overall survival of HPV patients who received radiotherapy $(\mathrm{p}=0.005$ and 
$\mathrm{p}=0.007)$ [17]. Another research also determined predictive value of having HPV for patients with CC [18].

Thus, differently located virus-negative tumors have the worst prognosis and response to treatment. As for cervical cancer, we can say that large majority of tumors are HPV-positive, and for such kind of tumors an additional virus-associated prognosis criterion is needed, one which would allow to determine those patients from an HPV-positive group who have favorable and unfavorable prognosis.

It is known that $90 \%$ of healthy women have HPV infection spontaneously eliminated from their organisms [19]. The possibility of virus elimination from the host cell is determined by many factors, including the physical status of HPV DNA. Episomal form of HPV leads to HPV being eliminated in most cases, with no dysplasia and CC [7]. Integrated form of the virus exists for a longer period of time, which is why it is detected in high-grade epithelial dysplasia and CC. It induces proliferative processes in cells, genomic instability, and mutations [20,21]. Due to this, it is interesting to study the connection between the physical status of the virus and survival of $\mathrm{HPV}+$ patients.

\section{Patients and methods}

Patients characteristics. The study involved 140 inhabitants of the Tomsk Region aged from 21 to 79 years diagnosed with primary CC of stages I-IVA, who were examined and treated in Tomsk Cancer Research Institute. The diagnosis was verified histologically; the tumors were described according to the FIGO classification. The volume of surgical treatment depends on the stage of the disease. So, in stage

Table 1. Comparison of the basic clinical and pathological values of $\mathrm{HPV}+$ and HPV- patients.

\begin{tabular}{lcccc}
\hline Clinical and pathological parameter & $\begin{array}{c}\text { HPV+ } \\
(\mathbf{n = 1 0 8})\end{array}$ & $\begin{array}{c}\text { HPV- } \\
(\mathbf{n}=\mathbf{3 2})\end{array}$ & p-value \\
\hline Histologic type & Squamous & $106(98.1 \%)$ & $30(93.8 \%)$ & \\
& Adenocarcinoma & $2(1.9 \%)$ & $2(6.3 \%)$ & 0.224 \\
Age, year & & $42.1 \pm 1.7$ & $45.5 \pm 1.6$ & 0.461 \\
Tumor size & $\mathrm{T} 1$ & $35(32.4 \%)$ & $10(31.3 \%)$ & 0.542 \\
& $\mathrm{~T} 2$ & $45(41.7 \%)$ & $13(40.6 \%)$ & 0.541 \\
& $\mathrm{~T} 3$ & $25(23.1 \%)$ & $6(18.7 \%)$ & 0.397 \\
& $\mathrm{~T} 4$ & $3(2.8 \%)$ & $3(9.4 \%)$ & 0.132 \\
Lymph node status & $\mathrm{N} 0$ & $98(90.7 \%)$ & $29(90.6 \%)$ & \\
& $\mathrm{N} 1$ & $10(9.3 \%)$ & $3(9.4 \%)$ & 1 \\
Pregnancy & & $4.5 \pm 0.4$ & $4.7 \pm 0.59$ & 0.886 \\
Parturition & & $1.6 \pm 0.1$ & $1.5 \pm 0.2$ & 0.862 \\
Abortions & & $2.6 \pm 0.3$ & $2.6 \pm 0.5$ & 0.929 \\
Miscarriage & & $15(13.9 \%)$ & $7(21.9 \%)$ & 0.306 \\
Mioma & & $27(25.0 \%)$ & $10(31.3 \%)$ & 0.499 \\
Ectropion/erosion & & $76(70.4 \%)$ & $22(68.8 \%)$ & 1 \\
PIS (pelvic inflammatory diseases) & $38(35.2 \%)$ & $11(34.4 \%)$ & 1 \\
\hline
\end{tabular}

IA2 patients received surgical treatment in the extent of radical trachelectomy combined with pelvic lymphadissection, in stages IB-IIA patients received combined treatment in the extent of extended extirpation uterus with/without appendages followed by radiotherapy, in patients with locally advanced cervical cancer (stages IIB-IIIA) chemo-radiation therapy was conducted.

As a study material, we used endocervical scraping and external orifice scraping samples. All patients underwent detection and genotyping of HPV DNA. We distinguished a group of patients who were HPV carriers $(n=108)$; patients with type $16 \mathrm{HPV}$ (monotype or in combination with other types) also underwent type $16 \mathrm{HPV}$ DNA physical status determination.

Detection and genotyping of HPV DNA was performed via multiplex polymerase chain reaction (PCR) in real time using RotorGene 6000 (Corbette Research, Australia) device and sets of reagents produced by Amplisens" ("AmpliSens $^{\circledast}$ HPV HCR-screen-titre-FL"; "AmpliSens ${ }^{\star}$ HPV HCR-genotype-FL"). HPV16 DNA physical status was determined using the "AmpliSens" ${ }^{\oplus}$ HPV HCR-screen-titre-FL" (with differentiation of genotype 16), (Moscow, Russia). The value of viral load was calculated in genomic equivalents of HPV DNA $/ 10^{5}$ cells, relevant viral load threshold was set to $3 \mathrm{lg}$ HPV DNA $/ 10^{5}$ cells in a scraping. Detection of E6 region with E1/E2 region missing was interpreted as HPV integration into the human DNA, detection of E6 region with E1/E2 region - as mixed form/partial integration of the virus into the human DNA, and missing E6 region with E1/E2 region as an episomal form of the virus.

Statistical analyses. For evaluation of statistical relevance of differences in distribution of qualitative characters' occurrence between groups, Fisher's two-tailed test has been used http://vassarstats.net/odds $2 \times 2 . h t m l$. For quantitative characters we used Mann - Whitney U-test. Survival evaluation was performed via the Kaplan-Meier estimator.

\section{Results}

Survival of HPV+ and HPV- patients with CC. 108 patients $(77.1 \%)$ were diagnosed with one of the several types of HPV, and 32 patients (22.9\%) had HPV-negative tumors. We gathered samples from HPV-negative patients one more time, isolated the DNA, identified and genotyped HPV in the studied samples. Absence of HPV was verified as a result. Based on HPV status, the patients were divided into 2 study groups: HPV-positive $(\mathrm{n}=108)$ and HPV-negative patients $(n=32)$. The groups did not differ in terms of the basic clinical and pathological values: tumor size, lymphatic cancer spread and histotype and more (Table 1).

Studying the survival, we noted a decline in both relapsefree survival $(\mathrm{p}=0.02)$ and overall survival $(\mathrm{p}=0.0009)$ in HPV-negative patients with CC compared to HPV+ (Figure 1a, 1b). The relapse-free survival median for HPVwas 20 months, the overall survival was 37 months. For 
the HPV+ group, the medians of relapse-free and overall survival were not reached in 68 and 123 months of the study, respectively (Figure 1). Thus, our study proved the predictive value of HPV infection for patients with CC. HPV+ patients showed high relapse-free and overall survival rates.

Survival of HPV+ patients with CC based on a viral load. It is well-known that viral load is connected to a risk of CC development in patients with dysplasia. Viral load of less than $10^{5}$ genomic equivalents (GE) HPV HCR in a scraping or $10^{3} \mathrm{GE}$ for $10^{5}$ human cells is considered clinically irrelevant, because it almost never occurs in high-grade dysplasia and CC, and it is associated with a minimal risk of their development. On the contrary, viral load more than $10^{5} \mathrm{GE}$ for $10^{5}$ cells is considered high, it is associated with a higher risk of high-grade dysplasia development, and occurs more often in cases of CC [22].

Our study showed that the number of patients with low viral load was $19.5 \%$ and $80.5 \%$ of patients had clinically relevant viral load. Relapse-free and overall survival of $\mathrm{HPV}+$ patients was evaluated depending on the type of the viral load (Figure 2). We did not detect statistically relevant differences for this value. Thus, viral load does not possess the predictive value for HPV+ patients with CC.

Survival of $\mathrm{HPV}+$ patients with $\mathrm{CC}$ based on the physical status of the virus. Out of the $108 \mathrm{HPV}+$ patients with CC, 87 (80.6\%) had type 16 HPV (monotype or a combination of it with other types). The physical status of their viral DNA was studied. The rest of the patients had other types of the virus: type $31 \mathrm{HPV}-8$ patients (7.4\%), type $33 \mathrm{HPV}$ - 6 patients $(5.6 \%)$, type $56 \mathrm{HPV}-4$ patients (3.7\%), types 45/52 HPV - 3 patients (2.8\%), types 39/51/58/59 HPV - 2 patients (1.9\%). According to our previous studies, infection of women with CC with type $16 \mathrm{HPV}$ was higher and equaled $85.0 \%$ [23]. It is known that integration of HPV into the cell genome is considered one of the main factors for high-grade dysplasia development and tumor transforma-
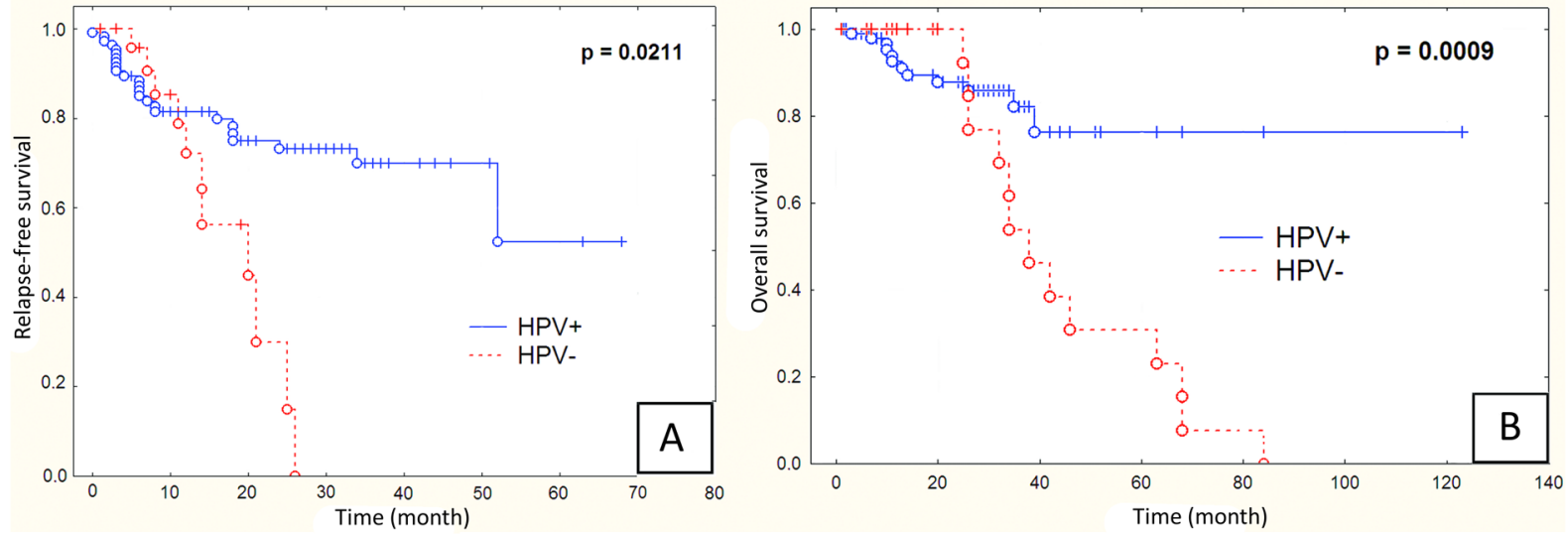

Figure 1. Relapse-free survival (A) and overall survival (B) of HPV+ and HPV-patients with cervical cancer; the method Kaplan-Meier.
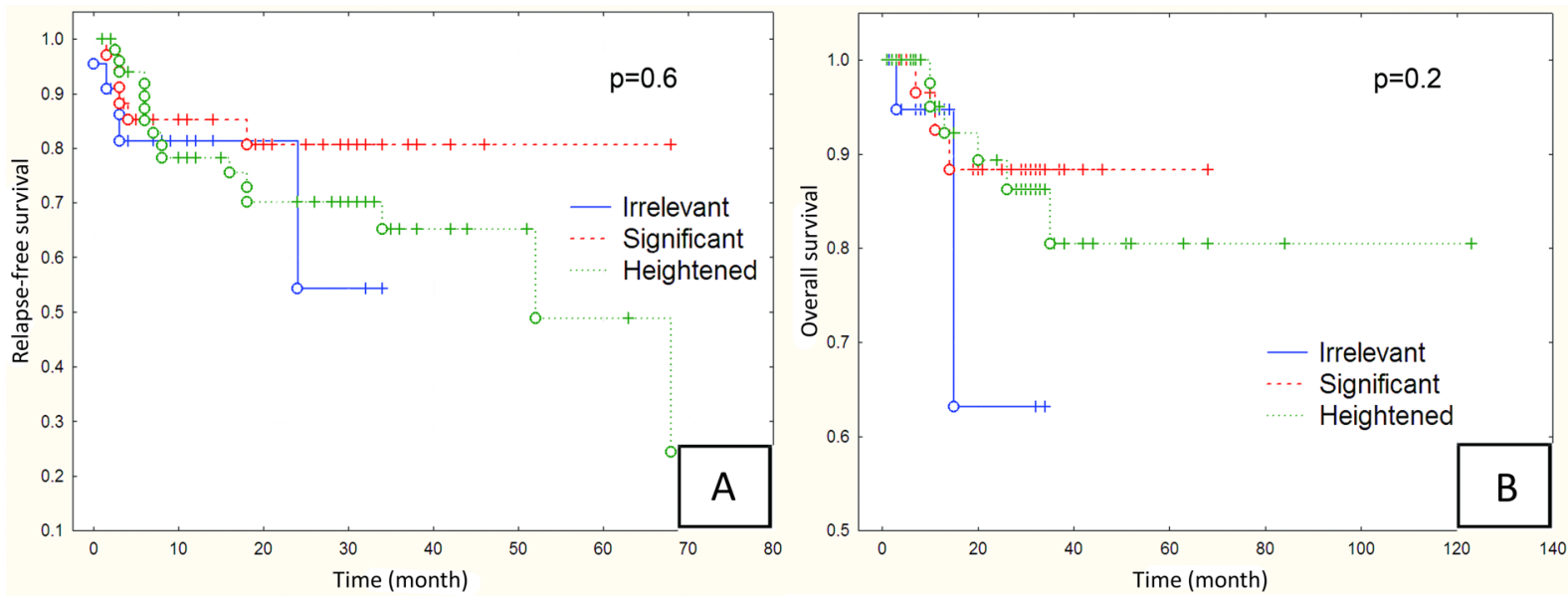

Figure 2. Relapse-free survival (A) and overall survival (B) of HPV+ patients with cervical cancer based on the type of viral load; the method Kaplan-Meier. 
tion of cervix epithelium [10,11]. According to the results of not numerous research, integrated form of HPV DNA occurs in not more than $35 \%$ of cases depending on the grade of dysplasia, and episomal form is rarer - up to $15 \%$ of cases $[24,25]$. Our research showed that incidence of type $16 \mathrm{HPV}$ forms distributed in the following manner: episomal form occurred in $8.9 \%$ of cases, mixed and integrated in $64.6 \%$ and $26.5 \%$ of cases, respectively, which does not contradict the literature data.

The next step was to study the outcome of the disease depending on the physical status of the virus. Figures $3 \mathrm{a}$ and $3 \mathrm{~b}$ demonstrate relapse-free and overall survival of patients with CC depending on the physical status of type $16 \mathrm{HPV}+$, and it also shows the data on the HPV- group for comparison. It was determined that distribution of relapse-free and overall survival for all four groups of patients is statistically relevant. Patients with episomal form of HPV16 show 100\% of relapse-free and overall survival. The median of relapsefree survival for patients with mixed HPV16 was 52 months, the median of overall survival was not reached. This is higher than the values for HPV- patients, who have median of relapse-free and overall survival of 20 and 37 months. The most unfavorable outcomes occur in patients with integrated form of HPV16. The relapse-free survival median for them was 7 months, the overall one was 25 months.

We compared the basic clinical and pathological parameters for patients of all four groups represented, and no statistically relevant differences in parameters distribution were registered (data not presented). Moreover, overall and disease-free survival in patients with locally advanced cervical cancer (stage IIB-IIIA) has been studied. This group of patients also presented with similar differences in survival among patients depending on the physical status of the virus (Figure 4). This means that the physical status of HPV is an independent factor of CC prognosis.

Thus, as a result of the study the predictive value of the physical status of type $16 \mathrm{HPV}$ was determined for relapsefree and overall survival of patients with CC. Episomal form of the virus is a favorable predictive factor. Integrated form of the virus is a severely unfavorable predictive factor and survival of such patients is significantly lower than that of HPV- patients and patients with mixed form of the virus.
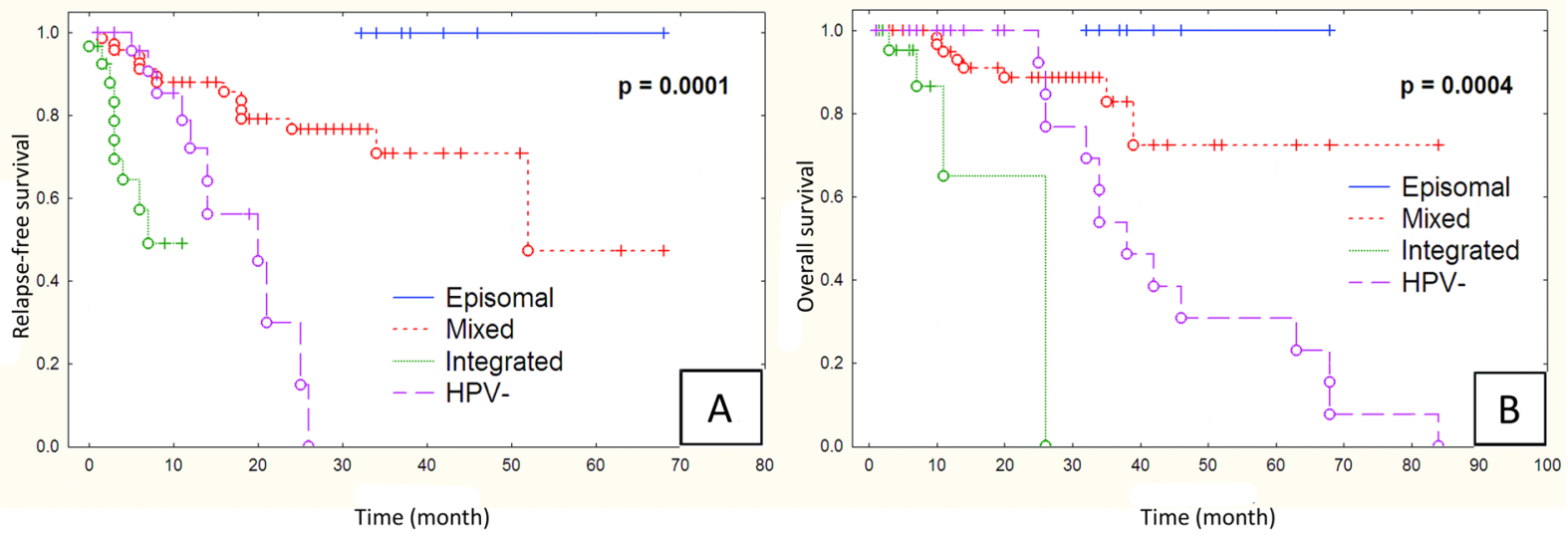

Figure 3. Relapse-free survival (A) and overall survival (B) of patients with cervical cancer; the method Kaplan-Meier.
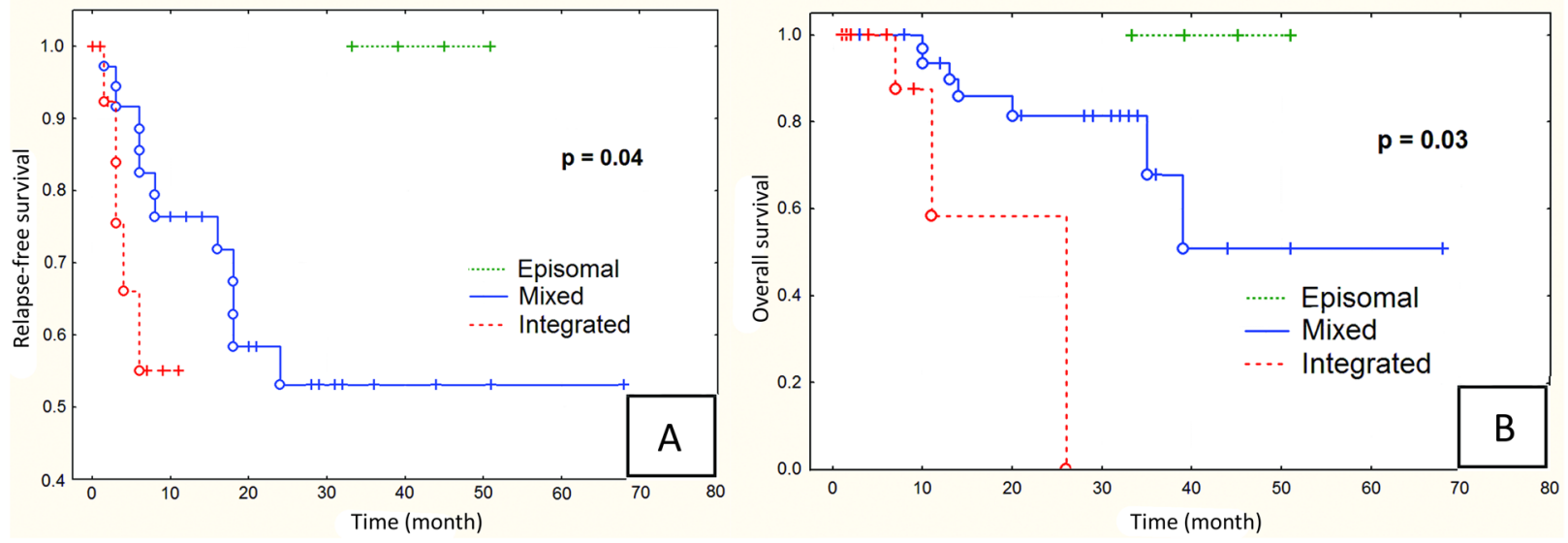

Figure 4. Relapse-free survival (A) and overall survival (B) of patients with locally advanced cervical cancer (stage IIB-IIIA); the method Kaplan-Meier. 


\section{Discussion}

During the study, we determined that the presence or absence of viral element in patients with cervical cancer is a relevant predictive parameter. We have noted a decline in relapse-free and overall survival for patients with CC in the group of $\mathrm{HPV}$ - patients. It is possible that prevalence of more aggressive forms in $\mathrm{HPV}$-negative $\mathrm{CC}$ is no coincidence, and decline in survival of such patients may be explained by different mechanisms of CC carcinogenesis, which may explain the reason for differences in disease outcomes. The study by Harima et al showed that HPV-negative cancers are a separate group and this subtype responds to the radiotherapy the worst [17]. Holm, R. et al (2008) showed that rates of overall survival for HPV- patients with CC are lower by a statistically relevant margin $(\mathrm{p}=0.03)$. The authors explain it by mutations of the TP53 gene in 50\% of HPV-cancers and on that basis, they consider it to be more aggressive [18].

There was a report in 2006 where the HPV viral load in endocervical scrapings of patients with CC taken before treatment was studied. It showed that according to the severity of prognosis, CC are ranked in the following way: HPV-positive tumors with high viral load, HPV-positive tumors with low viral load, and prognoses are the worst for HPV-negative tumors [26].

Now it is known that the HPV DNA viral load may reflect the severity and prognosis of progress of HPV. The study by Cricca M. et al. showed that presence of the viral DNA in the amount lesser than certain threshold is associated with a high probability of spontaneous elimination of the causative agent and absence of risks for progression of cervix epithelium damage [24]. Lastly, it is not unreasonable to monitor the viral load. It is believed that decline of the amount of HPV DNA by more than $1 \mathrm{lg}$ may be a marker of transient infection. In such case, growth of the viral load in 3, 6, and 9 months after treatment indicates a possible relapse $[27,28]$.

A number of authors state that viral load is not only associated with severity of dysplasia, but it also determines the probability of a relapse $[29,30]$. We did not determine the predictive value of viral load for relapse-free and overall survival in patients with CC. This corresponds with the results by Szóke et al., who showed absence of influence of viral load on progress of the tumors [31].

Despite the fact that the viral load is recognized by many authors as a prognostic factor for the development and progression of cervical disease, the relationship between initial HPV viral load and prognosis of cervical cancer patients has not yet been clearly defined. Ting Deng et al. reviewed a total of $346 \mathrm{HPV}+$ patients with stage IA-IIIA cervical cancer. The authors reported that the viral load was not correlated with parameters such as age, stage, histological type, lymph node metastases and tumor size. Low HPV viral load showed significant relationship with poor disease-free survival $(p=0.037)$. No statistically significant difference in overall survival was observed between patients with low and high viral load (5-year follow-up) [32]. Das et al. analyzed 132 pretreatment cervical tumor biopsies from patients positive for HPV16 and evaluated the effect of viral load and E6/E7 oncogene expression on the clinical outcome of patients. Survival analysis was done by Kaplan-Meier method. Neither the viral load nor the expression of the viral oncogenes showed significant association with the overall and recurrence-free survival $(\mathrm{p}>0.05)$ [33]. Our results were consistent with the above mentioned studies, indicating that HPV load did not have prognostic significance in cervical cancer patients. However, several studies reported about the correlation between the viral load and recurrence-free survival, with p-values between 0.00 and $0.05[34,35]$. Thus, the prognostic significance of pretreatment HPV load in cervical cancer is still controversial. Even if the prognostic significance of the viral load will be confirmed in future studies, the penetrance of this marker with respect to the outcome of cervical cancer will likely be low.

Various sources suggest that we may use types of HPV, their combination, viral load, and integration of viral DNA into the host cell genome as predictive factors of CC. In addition, integration of HPV into the cell genome is considered one of the main factors for high-grade dysplasia development and tumor transformation of cervix epithelium [10, 11]. In this research, we studied the physical status and the degree of integration of virus DNA in 87 cervical samples containing HPV16 (monotype or a combination of it with other types). In this study, we showed that incidence distribution of episomal, mixed, and integrated forms of HPV16 correspond with the literature data $[24,25]$.

Our study compared survival depending on the physical status of the virus for HPV16+ patients, and also compared it to the survival of HPV- patients. We determined statistically relevant differences in overall and relapse-free survival between HPV- patients with episomal, mixed, or integrated forms of virus. Patients with episomal form proved to have the highest rates of overall and relapse-free survival followed by the group of patients with mixed form of type $16 \mathrm{HPV}$, then HPV-negative patients, and the most unfavorable prognosis have patients with integrated form of type $16 \mathrm{HPV}$. Moreover, as we have shown, among HPV 16+ examined the frequency of an integrated and mixed forms of HPV increased with worsening morphological reconstruction of cervical epithelium. It is reasonable to suggest that the presence of an integrated form of the virus may be considered as a risk factor for prognosis of cervical intraepithelial neoplasia and cervical cancer [36].

There are few researches on survival of patients depending on the physical status of human papilloma virus. One part of the studies denies the fact that there is a connection of patients' survival with the physical status of HPV, other research shows that episomal form of HPV is the most favorable predictive factor compared to integrated form of the virus. Thus, in the study by Holm R. et al. the use of this parameter as a predictive factor in cervical cancer is discussed. Study of survival was 
performed on 202 women with CC. No statistically relevant differences of overall survival between patients with episomal and integrated forms of the virus were determined [18].

Another study was dedicated to the physical status of human papilloma virus of genotypes 16 and 18 including the examination of 75 patients with CC and showed that incidence of episomal form was much higher for HPV16 (43.3\%) than for HPV18 (10.0\%) ( $\mathrm{p}=0.011)$. Average patient age with episomal form of HPV16 (48.5 \pm 9.2$)$ was statistically much higher than that of patients with integrated form of HPV16 (42.5 \pm 9.4$)(\mathrm{p}=0.02)$, and the older age group (older than 50) showed higher incidence of episomal form of HPV16 than integrated form of HPV ( $p=0.041)$. As for other clinical and pathological parameters evaluated in the research, the physical status of types 16 and $18 \mathrm{HPV}$ did not show any statistically relevant correlation. As to comparison of survival in groups of patients with episomal and integrated forms, it was shown that patients with episomal form of HPV16 had the best prognosis and their two-year overall and relapse-free survival was $27.0 \%$ higher than that of patients with integrated form of HPV, even though the data was not statistically relevant $(\mathrm{p}=0.49)$. The common conclusion by the authors of this study is that not only did the clinical and pathological parameters not show a relevant association with disease prognosis, but also the two-year overall and relapsefree survival of patients is not connected with the presence of different types of HPV and their physical status [37].

The data were obtained as a trend from the research by Vernon et al. (1997). A small set of samples (41 patients) was the basis for study of survival depending on the physical status of HPV and it showed that four-year relapse-free survival was $38.4 \%$ for patients with integrated HPV 16 DNA compared to $80.0 \%$ in patients with episomal or mixed form of the virus $(\mathrm{p}=0.06)$ [38].

In a research by Das et al. [33] the authors were observing 132 patients with CC for 18 months. All the patients were HPV16+. Integrated form (they merged groups of mixed and integrated forms into one) of HPV was detected in $86.0 \%$ of cases (114 patients), and 18 patients were carriers of episomal form of the virus. The study evaluated survival in 3 parameters: viral load, level of E6/E7 oncogenes expression, and physical status of the virus. It was shown that neither the group of patients with high and low viral load, nor groups with high and low levels of E6/E7 expression showed differences in overall and relapse-free survival. However, the results showed that patients with episomal form had better overall and relapse-free survival compared to the patients with integrated form $(\mathrm{p}=0.005)$. Multivariant analysis showed that of all three studied parameters, the physical status is the most relevant predictive factor, and that integrated form is associated with decline in relapse-free survival [38].

Acknowledgements: The research is financially supported by the UMNIK program of the Innovation Support Foundation of Russian Federation (project № 11852GU/2017).

\section{References}

[1] CHISSOV V, STARINSKIY V, PETROVA G (Eds.). In: Malignant neoplasms in Russia in 2009 (incidence and mortality). P.A. Herzen Moscow Oncology Research Institute, Moscow, 2011, p. 259. ISBN 9785-85502-046-0.

[2] BOSCH FX. Human papillomavirus: science and technologies for the elimination of cervical cancer. Expert Opin Pharmacother 2011; 12: 2189-2204. https://doi.org/10.1517/1465 6566.2011.596527

[3] ZUR HAUSEN H. Papillomaviruses in the causation of human cancers - a brief historical account. Virology 2009; 384: 260-265. https://doi.org/10.1016/j.virol.2008.11.046

[4] TUNGTEAKKHUN SS, DUERKSEN-HUGHES PJ. Cellular binding partners of the human papillomavirus E6 protein. Arch Virol 2008; 153: 397-408. https://doi.org/10.1007/ s00705-007-0022-5

[5] ZUR HAUSEN H. Papillomaviruses and cancer: from basic studies to clinical application. Nat Rev Cancer 2002; 2: 342 3450. https://doi.org/10.1038/nrc798

[6] JIANG M, BASEMAN JG, KOUTSKY LA, FENG Q, MAO $\mathrm{C}$ et al. Sequence variation of human papillomavirus type 16 and measurement of viral integration by quantitative PCR. J Clin Microbiol 2009; 47: 521-526. https://doi.org/10.1128/ JCM.02115-08

[7] ROGOVSKAYA SI, SHABALOVA IP, MIKHEEVA IV, MINKINA GN, PODZOLKOVA NM et al. Human papillomavirus prevalence and type-distribution, cervical cancer screening practices and current status of vaccination implementation in Russian Federation, the Western countries of the former Soviet Union, Caucasus region and Central Asia. Vaccine 2013; 31: H46-58. https://doi.org/10.1016/j.vaccine.2013.06.043

[8] BOHMER G, VAN DEN BRULE AJ, BRUMMER O, MEIJER CL, PETRY KU. No confirmed case of human papillomavirus DNA-negative cervical intraepithelial neoplasia grade 3 or invasive primary cancer of the uterine cervix among 511 patients. Am J Obstet Gynecol 2003; 189: 118120. https://doi.org/10.1067/mob.2003.439

[9] KOMAROVA LE. [Current aspects of cytological screening for cancer of the cervix uteri: a review]. Opukholi Zhenskoi Reproduktivnoi Sistemy 2009, 34, 78-82.

[10] DAHLGREN L, DAHLSTRAND HM, LINDQUIST D, HÖGMO A, BJÖRNESTÅL L et al. Human papillomavirus is more common in base of tongue than in mobile tongue cancer and is a favorable prognostic factor in base of tongue cancer patients. Int J Cancer 2004; 112: 1015-1019. https:// doi.org/10.1002/ijc. 20490

[11] FAKHRY C, WESTRA WH, LI S, CMELAK A, RIDGE JA et al. Improved survival of patients with human papillomavirus-positive head and neck squamous cell carcinoma in a prospective clinical trial. J Natl Cancer Inst 2008; 100: 261 269. https://doi.org/10.1093/jnci/djn011

[12] LICITRA L, PERRONE F, BOSSI P, SUARDI S, MARIANI L et al. High-risk human papillomavirus affects prognosis in patients with surgically treated oropharyngeal squamous cell carcinoma. J Clin Oncol 2006; 24: 5630-5636. https://doi. org/10.1200/JCO.2005.04.6136 
[13] ANG KK, HARRIS J, WHEELER R, WEBER R, ROSENTHAL DI et al. Human papillomavirus and survival of patients with oropharyngeal cancer. N Engl J Med 2010; 363: 24-35. https://doi.org/10.1056/NEJMoa0912217

[14] DAYYANI F, ETZEL CJ, LIU M, HO CH, LIPPMAN SM et al. Meta-analysis of the impact of human papillomavirus (HPV) on cancer risk and overall survival in head and neck squamous cell carcinomas (HNSCC). Head Neck Oncol 2010; 2: 15. https://doi.org/10.1186/1758-3284-2-15

[15] O'RORKE MA, ELLISON MV, MURRAY LJ, MORAN $\mathrm{M}$, JAMES J et al. Human papillomavirus related head and neck cancer survival: a systematic review and meta-analysis. Oral Oncol 2012; 48: 1191-1201. https://doi.org/10.1016/j. oraloncology.2012.06.019

[16] SHAKHTAKHTINSKAYA AC, NAMAZOVA-BARANOVA LS, TATOCHENKO VK, NOVIKOVA DA, TKACHENKO NE. [Human Papilloma Virus. Prevention of HPV-associated diseases]. Pediatricheskaya Farmakologiya 2015; 12: 74-78.

[17] HARIMA Y., SAWADA S., NAGATA K., MITSUHARU S., TAKEO O. Human papilloma virus (HPV) DNA associated with prognosis of cervical cancer after radiotherapy. Int J Radiat Oncol Biol Phys 2002; 52: 1345-1351.

[18] HOLM R, KRAUS I, SKOMEDAL H, LANGERØD A, KRISTENSEN GB, LYNG H. Human papillomavirus DNA and e6/e7 mRNA status in relation to survival of patients treated for cervical squamous cell carcinoma. Open Virol J 2008; 2: 74-81. https://doi.org/10.2174/1874357900802010074

[19] STANLEY M. Pathology and epidemiology of HPV infection in females. Gynecol Oncol 2010; 117: 5-10. https://doi. org/10.1016/j.ygyno.2010.01.024

[20] HU Z, ZHU D, WANG W, LI W, JIA W et al. Genome-wide profiling of HPV integration in cervical cancer identifies clustered genomic hot spots and a potential microhomology-mediated integration mechanism. Nat Genet 2015; 47: 158-163. https://doi.org/10.1038/ng.3178

[21] VINK MA, BOGAARDS JA, VAN KEMENADE FJ, DE MELKER HE, MEIJER CJ et al. Clinical progression of highgrade cervical intraepithelial neoplasia: estimating the time to preclinical cervical cancer from doubly censored national registry data. Am J Epidemiol 2013; 178: 1161-1169. https:// doi.org/10.1093/aje/kwt077

[22] SASIENI P, CASTANON A, CUZICK J. Effectiveness of cervical screening with age: population based case-control study of prospectively recorded data. BMJ 2009; 339: b2968. https://doi.org/10.1136/bmj.b2968

[23] KOLOMIETS LA, CHURUKSAEVA ON, SHPILEVA OV, URAZOVA LN, RODICHEVA NS. [Prevalence of various human papillomavirus (HPV) types in patients with cervical intraepithelial neoplasia (CIN) and cervical cancer in Tomsk region]. Sibirskiy Onkologicheskiy Zhurnal 2012, 51, 41-45.

[24] CRICCA M, MORSELLI-LABATE AM, VENTUROLI S, AMBRETTI S, GENTILOMI GA et al. Viral DNA load, physical status and E2/E6 ratio as markers to grade HPV16 positive women for high-grade cervical lesions. Gynecol Oncol 2007; 106: 549-557. https://doi.org/10.1016/j.ygyno.2007.05.004
[25] SAUNIER M, MONNIER-BENOIT S, MAUNY F, DALSTEIN V, BRIOLAT J et al. Analysis of human papillomavirus type 16 (HPV16) DNA load and physical state for identification of HPV16-infected women with high-grade lesions or cervical carcinoma. J Clin Microbiol 2008; 46: 3678-3685. https://doi.org/10.1128/JCM.01212-08

[26] DATTA NR, KUMAR P, SINGH S, GUPTA D, SRIVASTAVA A et al. Does pretreatment human papillomavirus (HPV) titers predict radiation response and survival outcomes in cancer cervix? - A pilot study. Gynecol Oncol 2006; 103: 100-105. https://doi.org/10.1016/j.ygyno.2006.01.058

[27] SNIJDERS PJ, VERHOEF VM, ARBYN M, OGILVIE G, MINOZZI S et al. High-risk HPV testing on self-sampled versus clinician collected specimens: A review on the clinical accuracy and impact on population attendance in cervical cancer screening. Int J Cancer, 2013, 132, 2223-2236. https://doi. org/10.1002/ijc. 27790

[28] STEENBERGEN RD, SNIJDERS PJ, HEIDEMAN DA, MEIJER CJ. Clinical implications of (epi) genetic changes in HPV-induced cervical precancerous lesions. Nat Rev Cancer 2014; 14: 395-405. https://doi.org/10.1038/nrc3728

[29] ARBYN M, ANTTILA A, JORDAN J, RONCO G, SCHENCK $\mathrm{U}$ et al. European guidelines for quality assurance in cervical cancer screening. Ann Oncol 2010; 21: 448-458. https://doi. org/10.1093/annonc/mdp471

[30] PRATO B, GHELARDI A, GADDUCCI A, MARCHETTI I, DI CRISTOFANO C et al. Correlation of recurrence rates and times with posttreatment human papillomavirus status in patients treated with loop electrosurgical excision procedure conization for cervical squamous intraepithelial lesions. Int J Gynecol Cancer 2008; 18: 90-94. https://doi. org/10.1111/j.1525-1438.2007.00965.x

[31] SZOE K, SAPY T, KRASZNAI Z, HERNADI Z, SZLADEK $\mathrm{G}$ et al. Moderate variation of the oncogenic potential among high-risk human papillomavirus types in gynecologic patients with cervical abnormalities. J Med Virol 2003; 71: 585-592. https://doi.org/10.1002/jmv.10526

[32] DENG T, FENG Y, ZHENG J, HUANG Q, LIU J. Low initial human papillomavirus viral load may indicate worse prognosis in patients with cervical carcinoma treated with surgery. J Gynecol Oncol 2015; 26: 111-117. https://doi. org/10.3802/jgo.2015.26.2.111

[33] DAS P, THOMAS A, KANNAN S, DEODHAR K, SHRIVASTAVA SK et al. Human papillomavirus (HPV) genome status \& cervical cancer outcome-A retrospective study. Indian J Med Res 2015; 142: 525-532. https://doi. org/10.4103/0971-5916.171276

[34] CAO M, SHAH W, QI J, ZHOU Y, WANG Y et al. Prognostic significance of human papillomavirus viral load in correlation with different therapeutic modalities in cervical cancer patients. Pathol Res Pract 2016; 212: 804-810. https://doi. org/10.1016/j.prp.2016.06.011

[35] LUO H, BELINSON JL, DU H, LIU Z, ZHANG L et al. Evaluation of Viral Load as a Triage Strategy With Primary High-Risk Human Papillomavirus Cervical Cancer Screening. J Low Genit Tract Dis 2017; 21: 12-16. https://doi. org/10.1097/LGT.0000000000000277 
[36] IBRAGIMOVA MK, TSYGANOV MM, KARABUT IV, CHURUKSAEVA ON, SHPILEVA ON et al. [Integrative and episomal forms of genotype 16 of human papillomavirus in patients with cervical intraepithelial neoplasia and cervical cancer]. Voprosy Virusologii 2016; 61: 70-74.

[37] NAMBARU L, MEENAKUMARI B, SWAMINATHAN R, RAJKUMAR T. Prognostic significance of HPV physical status and integration sites in cervical cancer. Asian Pac J Cancer Prev 2009; 10: 355-360.
[38] VERNON SD, UNGER ER, MILLER DL, LEE DR, REEVES WC. Association of human papillomavirus type 16 integration in the E2 gene with poor disease-free survival from cervical cancer. Int J Cancer 1997; 74: 50-56. 